\title{
Socio-Economic Profile of the Union Members in APSRTC:A Case Study of Visakhapatnam City
}

\author{
R. Lydia ${ }^{1} \&$ B. Ravi Kumar ${ }^{2}$ \\ ${ }^{1}$ Department of MBA, Vijaya Institute of Management, India \\ ${ }^{2}$ Department of MBA, Amrita Sai Institute of Science and Technology, India
}

Correspondence: B. Ravi Kumar, Amrita Sai Institute of Science and Technology, India

To cite this article: Lydia, R., \& Kumar, B. R. (2018). Socio-Economic Profile of the Union Members in APSRTC:A Case Study of Visakhapatnam City. American International Journal of Social Science Research, 3(1), 13-21. Retrieved from http://www.cribfb.com/journal/index.php/aijssr/article/view/139

Received: August 15, 2018

Accepted: August 29, 2018

Online Published: September 6, 2018

\begin{abstract}
Trade unions help in accelerated pace of economic development in many ways. They are helping in the recruitment and selection of workers, inculcating discipline among the workforce, enabling settlement of industrial disputes in a rational manner and helping social adjustments with their activities. Workers have to adjust themselves to the new working conditions, the new rules and policies. Workers coming from different backgrounds may become disorganized, unsatisfied and frustrated. Unions will help them in such adjustment. The present study is an attempt to portray the socio-economic-profile of the sample respondents (union members) with reference to Visakhapatnam City.
\end{abstract}

Keywords: APSRTC, Age wise distribution, Caste, Gender wise distribution, Income wise distribution, Religion, Union Members, Visakhapatnam City.

\section{Introduction}

The existence of a strong and recognized trade union is a pre-requisite to industrial peace. Decisions taken through the process of collective bargaining and negotiations between employer and unions are more influential. Trade unions play an important role and are helpful in effective communication between the workers and the management. They provide the advice and support to ensure that the differences of opinion do not turn into major conflicts. The central function of a trade union is to represent people at work. But they also have a wider role in protecting their interests. They also play an important educational role, organizing courses for their members on a wide range of matters. Seeking a healthy and safe working environment is also prominent feature of union activity.

Trade unions are a part of society and as such, have to take into consideration the national integration as well. Some important social responsibilities of trade unions include promoting and maintaining national integration by reducing the number of industrial disputes, incorporating a sense of corporate social responsibility in workers and achieving industrial peace. Hence, the trade unionism in India developed quite slowly as compared to the western nations. Indian trade union movement can be divided into three phases.

2. Purpose of the Study

The primary objective of the study is to portray the socio-economic profile of the sample union members with reference to Visakhapatnam city. 


\begin{tabular}{cc}
\multicolumn{2}{c}{ Research Design } \\
\hline Sampling Area & Visakhapatnam City \\
\hline Sample Size & 200 \\
\hline Sampling Unit & APSRTC \\
\hline Sampling Method & Convenience sampling \\
\hline
\end{tabular}

\section{Results and Discussion}

Table - 1: Gender wise distribution of the sample union members in APSRTC

\begin{tabular}{|c|c|c|c|c|}
\hline \multirow[t]{2}{*}{ Gender } & \multicolumn{3}{|c|}{ Unions } & \multirow[t]{2}{*}{ Total } \\
\hline & NMU & $\mathbf{E U}$ & CITU & \\
\hline Male & $\begin{array}{l}116 \\
(77.3)\end{array}$ & $\begin{array}{l}28 \\
(93.3)\end{array}$ & $\begin{array}{l}20 \\
(100.0)\end{array}$ & $\begin{array}{l}164 \\
(82.0)\end{array}$ \\
\hline Female & $\begin{array}{l}34 \\
(22.7)\end{array}$ & $\begin{array}{l}2 \\
(6.7)\end{array}$ & - & $\begin{array}{l}36 \\
(18.0)\end{array}$ \\
\hline Total & $\begin{array}{l}150 \\
(100.0)\end{array}$ & $\begin{array}{l}30 \\
(100.0)\end{array}$ & $\begin{array}{l}20 \\
(100.0)\end{array}$ & $\begin{array}{l}200 \\
(100.0)\end{array}$ \\
\hline
\end{tabular}

Figure - 1:Gender-wise distribution of the sample union members in APSRTC

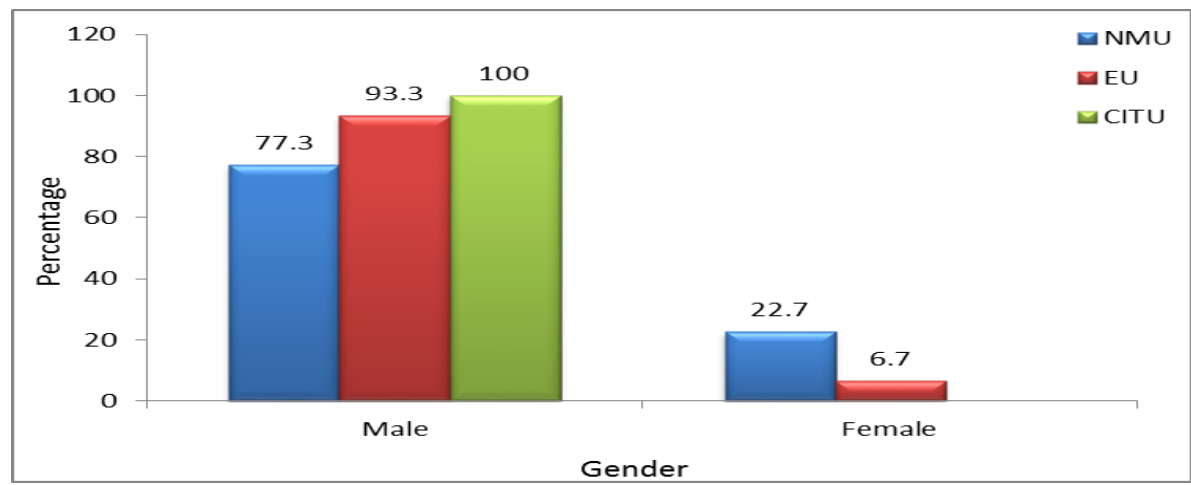

The table 1: shows the distribution of male and female employees in APSRTC working under three different unions. The above table depicts out of total employees $4 / 5^{\text {th }}$ employees are male as male are more preferred to this trade compared to females and in that most of the employees are working under NMU union compared to EU and CITU.

Table - 2: Age wise distribution of the sample union members in APSRTC

\begin{tabular}{ccccc}
\hline Age & \multicolumn{3}{c}{ Unions } & Total \\
\cline { 2 - 4 } & NMU & EU & CITU & \\
\hline 20-29 years & 26 & 3 & - & $\mathbf{2 9}$ \\
& $(17.3)$ & $(10.0)$ & & $(\mathbf{1 4 . 5})$ \\
\hline 30-39 years & 69 & 5 & 13 & $\mathbf{8 7}$ \\
& $(46.0)$ & $(16.7)$ & $(65.0)$ & $\mathbf{( 4 3 . 5 )}$ \\
\hline 40-49 years & 38 & 14 & 3 & $\mathbf{5 5}$ \\
& $(25.3)$ & $(46.7)$ & $(15.0)$ & $(\mathbf{2 7 . 5 )}$ \\
\hline 50-59 years & 17 & 8 & 4 & $\mathbf{2 9}$ \\
& $(11.3)$ & $(26.7)$ & $(20.0)$ & $\mathbf{( 1 4 . 5 )}$ \\
\hline Total & $\mathbf{1 5 0}$ & $\mathbf{3 0}$ & $\mathbf{2 0}$ & $\mathbf{2 0 0}$ \\
& $\mathbf{( 1 0 0 . 0 )}$ & $\mathbf{( 1 0 0 . 0 )}$ & $\mathbf{( 1 0 0 . 0 )}$ & $\mathbf{( 1 0 0 . 0 )}$ \\
\hline
\end{tabular}




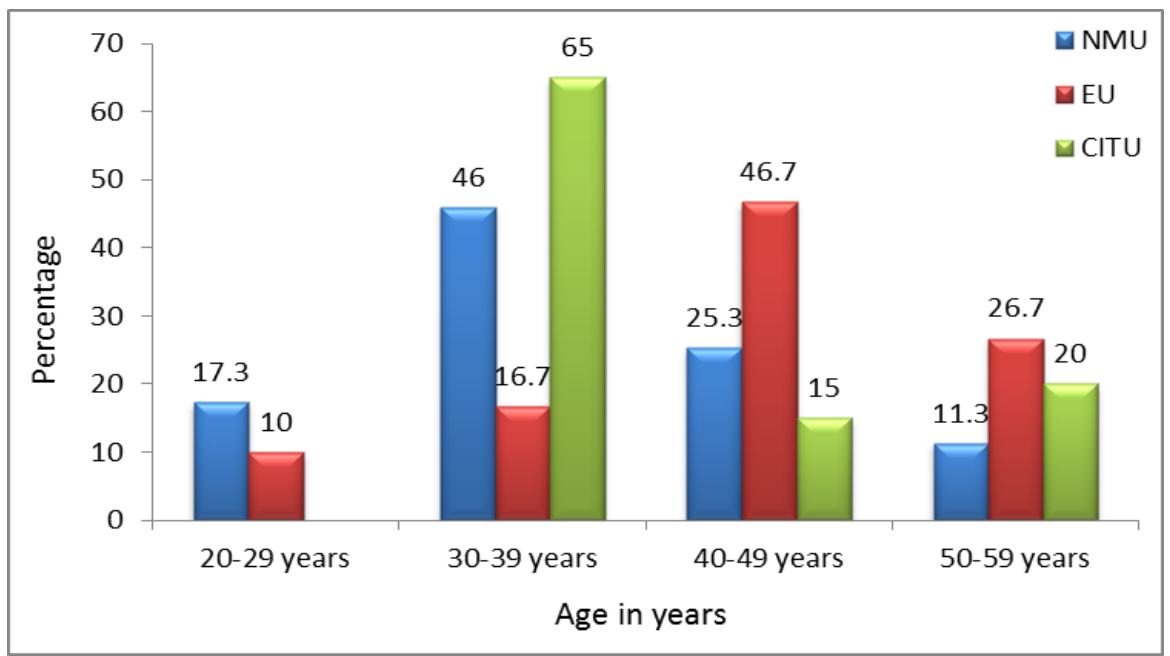

Figure - 2: Age wise distribution of the sample union members in APSRTC

The above table 2: shows the age wise distribution of the employees working under three unions. Most of the employees are working under NMU union and When the total employees are distributed age wise most of them (43.5\%) are of age group 30-39 years which indicates earning age group(30-39yrs) are preferring as a union members when compare with other age groups.

Table - 3: Distribution of the sample union members by their religion

\begin{tabular}{|c|c|c|c|c|}
\hline \multirow[t]{2}{*}{ Religion } & \multicolumn{3}{|c|}{ Unions } & \multirow[t]{2}{*}{ Total } \\
\hline & NMU & $\mathbf{E U}$ & CITU & \\
\hline Hindu & $\begin{array}{l}114 \\
(76.0)\end{array}$ & $\begin{array}{l}19 \\
(63.3)\end{array}$ & $\begin{array}{l}14 \\
(70.0)\end{array}$ & $\begin{array}{l}147 \\
(73.5)\end{array}$ \\
\hline Muslim & $\begin{array}{l}7 \\
(4.7)\end{array}$ & $\begin{array}{l}1 \\
(3.3)\end{array}$ & - & $\begin{array}{l}8 \\
(4.0)\end{array}$ \\
\hline Christian & $\begin{array}{l}29 \\
(19.3)\end{array}$ & $\begin{array}{l}10 \\
(33.3)\end{array}$ & $\begin{array}{l}6 \\
(30.0)\end{array}$ & $\begin{array}{l}45 \\
(22.5)\end{array}$ \\
\hline Total & $\begin{array}{l}150 \\
(100.0)\end{array}$ & $\begin{array}{l}30 \\
(100.0)\end{array}$ & $\begin{array}{l}20 \\
(100.0)\end{array}$ & $\begin{array}{l}200 \\
(100.0)\end{array}$ \\
\hline
\end{tabular}

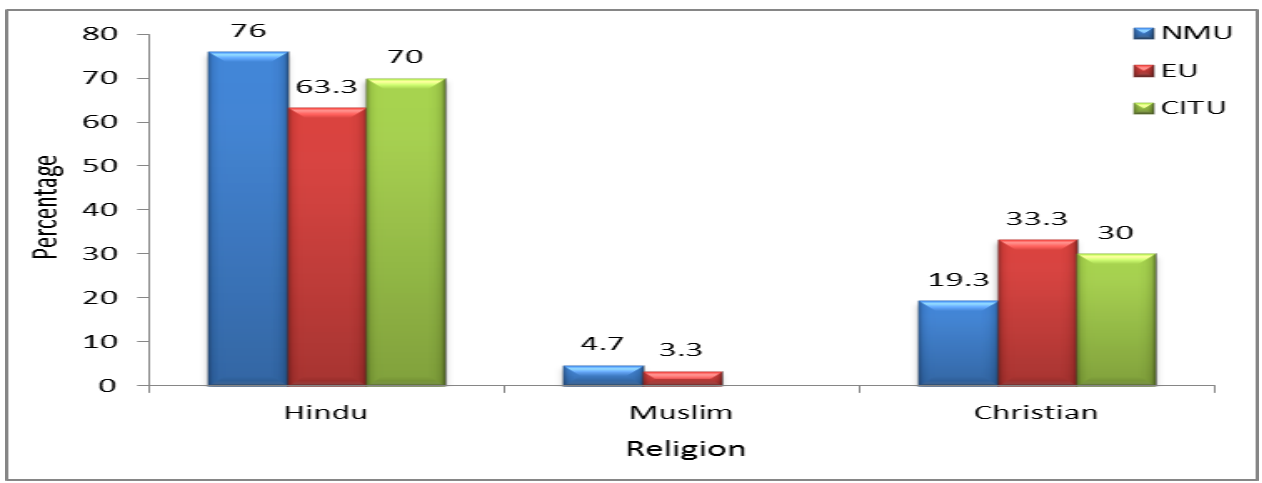

Figure - 3: Distribution of the sample union members by their religion

The above table 3: shows the distribution of employees according to their religion working under three different unions. Out of total employees most of them (75\%) are working under NMU union and in all three unions most of them are Hindus (73.5\%) and very less members are Muslims (4.0\%). 
Table- 4: Distribution of the sample union members by their Caste

\begin{tabular}{|c|c|c|c|c|}
\hline \multirow[t]{2}{*}{ Caste } & \multicolumn{3}{|c|}{ Unions } & Total \\
\hline & NMU & $\overline{\mathbf{E U}}$ & CIT & \\
\hline O.C & $\begin{array}{l}43 \\
(28.7)\end{array}$ & $\begin{array}{l}12 \\
(40.0)\end{array}$ & $\begin{array}{l}4 \\
(20.0)\end{array}$ & $\begin{array}{l}59 \\
(29.5)\end{array}$ \\
\hline B.C & $\begin{array}{l}76 \\
(50.7)\end{array}$ & $\begin{array}{l}8 \\
(26.7)\end{array}$ & $\begin{array}{l}9 \\
(45.0)\end{array}$ & $\begin{array}{l}93 \\
(46.5)\end{array}$ \\
\hline S.C & $\begin{array}{l}31 \\
(20.7)\end{array}$ & $\begin{array}{l}10 \\
(33.3)\end{array}$ & $\begin{array}{l}7 \\
(35.0)\end{array}$ & $\begin{array}{l}48 \\
(24.0)\end{array}$ \\
\hline Total & $\begin{array}{l}150 \\
(100.0)\end{array}$ & $\begin{array}{l}30 \\
(100.0)\end{array}$ & $\begin{array}{l}20 \\
(100.0)\end{array}$ & $\begin{array}{l}200 \\
(100.0)\end{array}$ \\
\hline
\end{tabular}

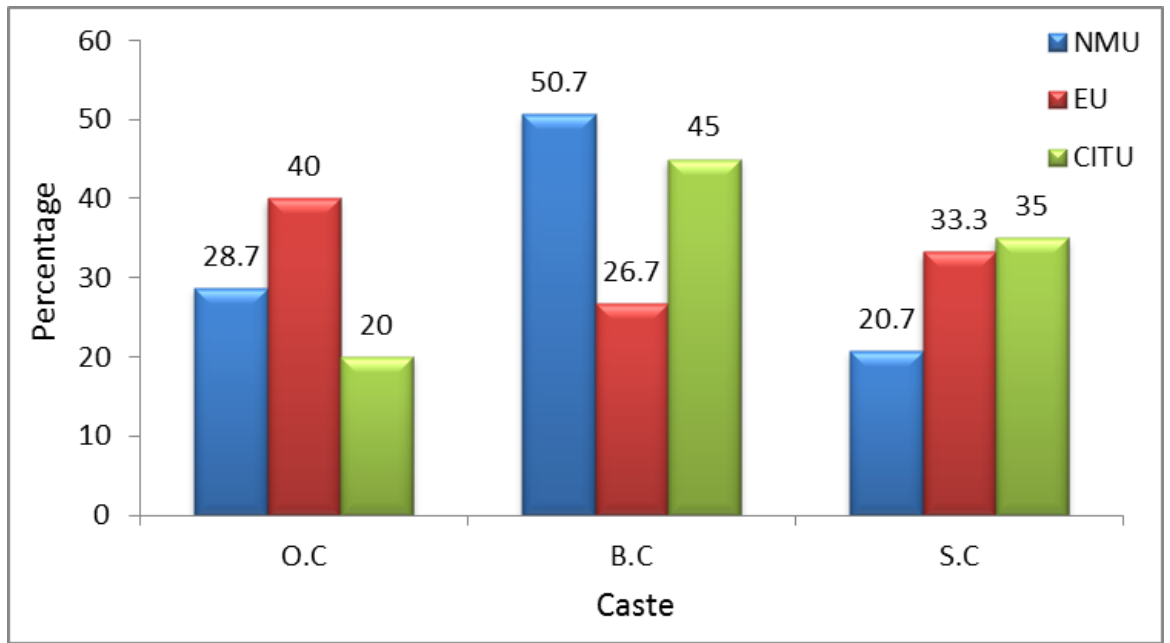

Figure -4 : Distribution of the sample union members by their caste

The above table 4: explains about the Caste of employees working under three different unions. Out of the total employees, $3 / 4^{\text {th }}$ are working in NMU union in which half of them belong to backward caste and in remaining half, open category employees are more compared to schedule caste. In EU union open category are more than Scheduled class and the least are Backward class of employees whereas in CITU Backward class are more compared to Schedule class and the least are open category.

Table - 5: Distribution of the sample union members of their marital status

\begin{tabular}{|c|c|c|c|c|}
\hline \multirow{2}{*}{ Marital status } & \multicolumn{3}{|c|}{ Unions } & \multirow{2}{*}{ Total } \\
\hline & NMU & $\mathbf{E U}$ & CITU & \\
\hline Unmarried & $\begin{array}{c}22 \\
(14.7)\end{array}$ & $\begin{array}{c}4 \\
(13.3)\end{array}$ & $\begin{array}{c}5 \\
(25.0)\end{array}$ & $\begin{array}{c}31 \\
(15.5)\end{array}$ \\
\hline Married & $\begin{array}{c}128 \\
(85.3)\end{array}$ & $\begin{array}{c}26 \\
(86.7)\end{array}$ & $\begin{array}{c}15 \\
(75.0)\end{array}$ & $\begin{array}{c}169 \\
(84.5)\end{array}$ \\
\hline Divorce & - & - & - & - \\
\hline Widower & - & - & - & - \\
\hline Total & $\begin{array}{c}150 \\
(100.0)\end{array}$ & $\begin{array}{c}30 \\
(\mathbf{1 0 0 . 0})\end{array}$ & $\begin{array}{c}20 \\
(100.0)\end{array}$ & $\begin{array}{c}200 \\
(100.0)\end{array}$ \\
\hline
\end{tabular}




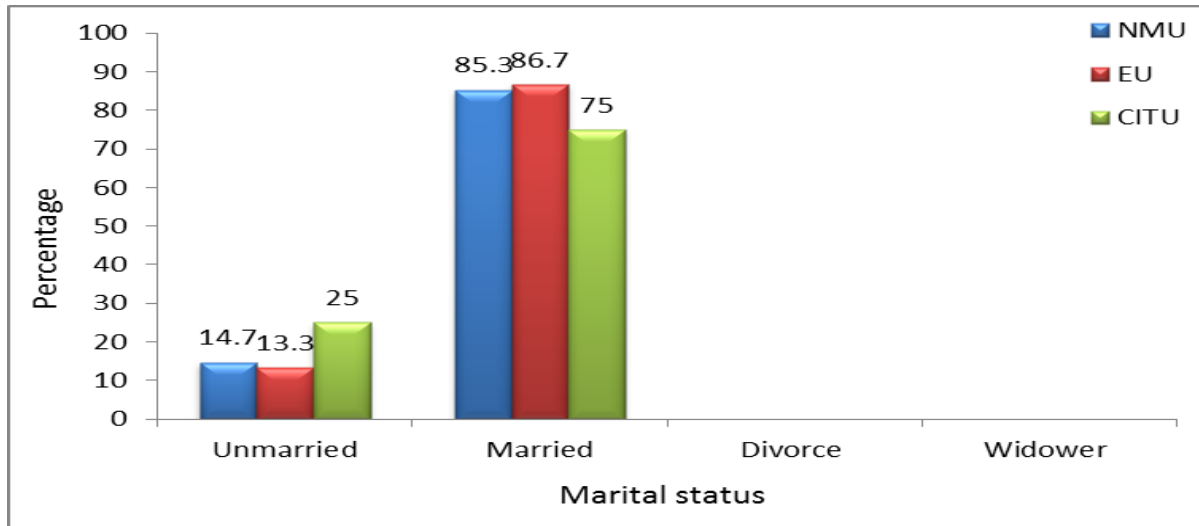

Figure - 5: Distribution of the sample union members of their marital status

The above table 5: shows the distribution of Unmarried and Married employees working under three different unions. Out of three unions employees working in NMU are more compared to EU and CITU and in overall $3 / 4^{\text {th }}$ are married and $1 / 4^{\text {th }}$ are unmarried which indicates married are more preferred to work in this Department compared to unmarried.

Table - 6: Distribution of the sample union members by their level of education

\begin{tabular}{ccccc}
\hline Level of education & \multicolumn{3}{c}{ Unions } & Total \\
\cline { 2 - 4 } & NMU & EU & CITU & \\
\hline Bellow SSC & 14 & 4 & 2 & $\mathbf{2 0}$ \\
& $(9.3)$ & $(13.3)$ & $(10.0)$ & $(\mathbf{1 0 . 0})$ \\
\hline SSC & 45 & 12 & 5 & $\mathbf{6 2}$ \\
& $(30.0)$ & $(40.0)$ & $(25.0)$ & $(\mathbf{3 1 . 0})$ \\
\hline Intermediate & 63 & 7 & 8 & $\mathbf{7 8}$ \\
& $(42.0)$ & $(23.3)$ & $(40.0)$ & $(\mathbf{3 9 . 0})$ \\
\hline Graduate & 24 & 5 & 4 & $\mathbf{3 3}$ \\
& $(16.0)$ & $(16.7)$ & $(20.0)$ & $(\mathbf{1 6 . 5})$ \\
\hline Post graduate & 4 & 2 & 1 & $\mathbf{7}$ \\
& $(2.7)$ & $(6.7)$ & $(5.0)$ & $\mathbf{( 3 . 5 )}$ \\
\hline Total & $\mathbf{1 5 0}$ & $\mathbf{3 0}$ & $\mathbf{2 0}$ & $\mathbf{2 0 0}$ \\
& $(\mathbf{1 0 0 . 0})$ & $(\mathbf{1 0 0 . 0})$ & $(\mathbf{1 0 0 . 0})$ & $\mathbf{( 1 0 0 . 0 )}$ \\
\hline & & & &
\end{tabular}

Figure - 6: Distribution of the sample union members by their level of education

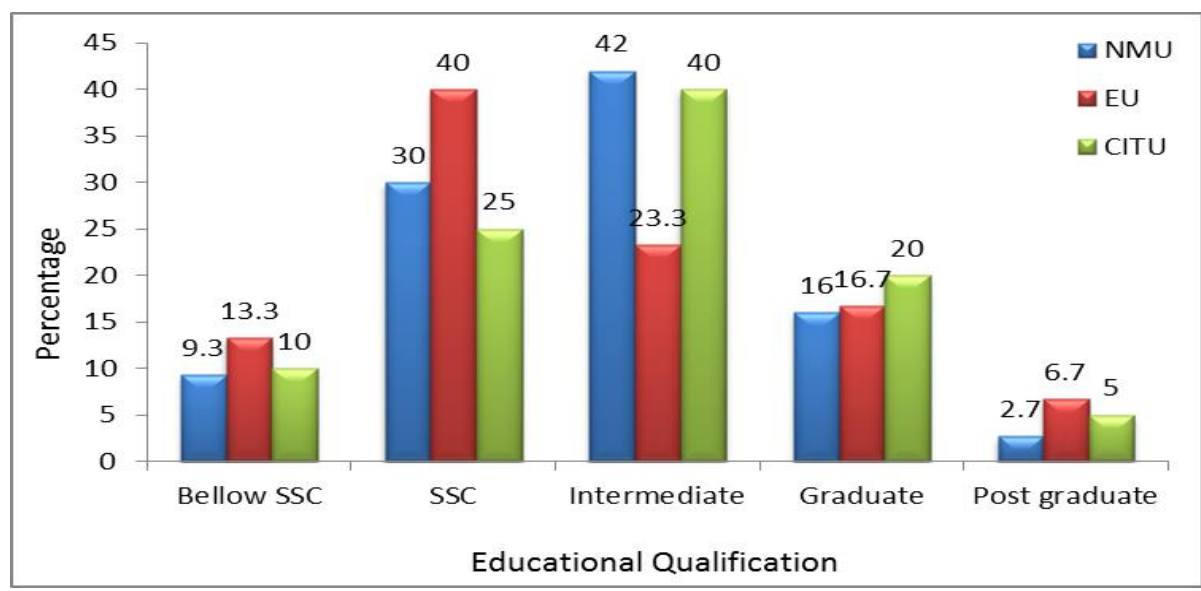

The above table 6: shows the level of education of the employees working under three unions. The above table 
depicts that out of total employees, employee with SSC and Intermediate qualification are more compared to other educational background which indicates higher qualification people (graduates \& post graduates) do not prefer to work in this particular trade.

Table - 7: Distribution of the sample union members by their designation

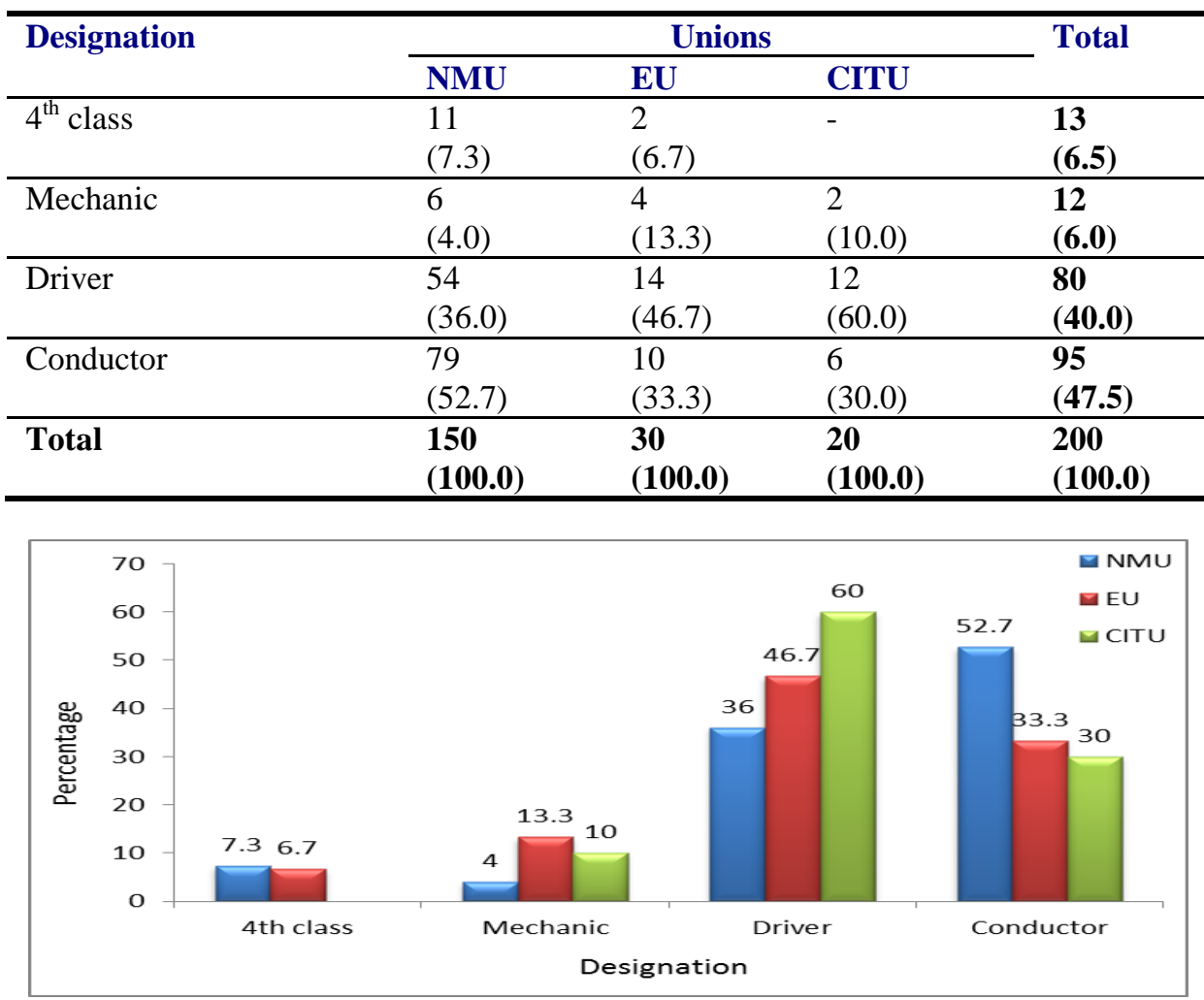

Figure-7: Distribution of the sample union members by their designation

The above table 7: shows the distribution of sample respondents in terms of their designation under three unions of employees. A significant amount of members are in NMU union working as conductors (52.7\%) followed by drivers (36\%). Among the EU, 46.7 percent of the employees are drivers, followed by 33.3 percent conductors, 13.3 percent mechanics and the least 6.7 percent are $4^{\text {th }}$ class employees. Whereas, under CITU 60.0 percent are drivers, followed by 30.0 percent conductors. Hence, overall conductors $(47.5 \%)$ dominate, followed by drivers $(40.0 \%)$.

Table - 8: Distribution of the sample union members by their traditional occupation of the family

\begin{tabular}{lllll}
\hline Family occupation & \multicolumn{3}{c}{ Unions } & \multirow{2}{*}{ Total } \\
\cline { 2 - 4 } & NMU & EU & CITU & \\
\hline Agriculture & 14 & 2 & 2 & $\mathbf{1 8}$ \\
& $(9.3)$ & $(6.7)$ & $(10.0)$ & $(\mathbf{9 . 0})$ \\
\hline Business & 9 & 2 & 2 & $\mathbf{1 3}$ \\
& $(6.0)$ & $(6.7)$ & $(10.0)$ & $(\mathbf{6 . 5})$ \\
\hline Caste Based Profession & 15 & 2 & 2 & $\mathbf{1 9}$ \\
& $(10.0)$ & $(6.7)$ & $(10.0)$ & $(\mathbf{9 . 5})$ \\
\hline Employment & 112 & 24 & 14 & $\mathbf{1 5 0}$ \\
& $(74.7)$ & $(80.0)$ & $(70.0)$ & $\mathbf{( 7 5 . 0 )}$ \\
\hline Total & & & & $\mathbf{2 0 0}$ \\
& $\mathbf{1 5 0}$ & $\mathbf{3 0}$ & $\mathbf{2 0}$ & $\mathbf{( 1 0 0 . 0 )}$ \\
\hline
\end{tabular}




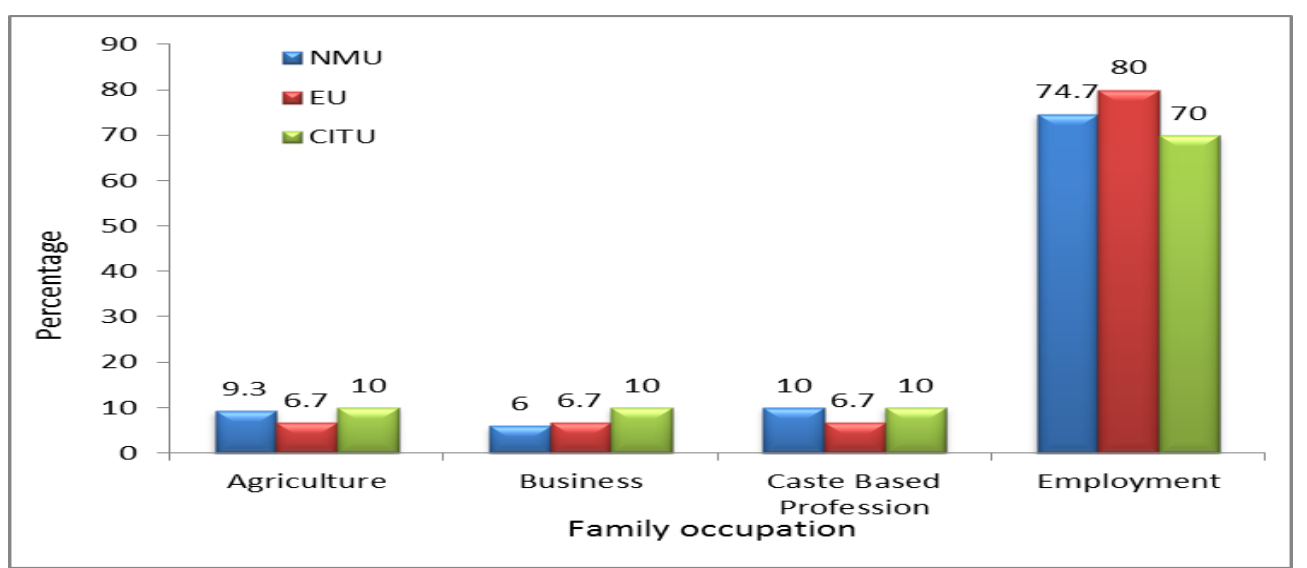

Figure - 8: Distribution of the sample union members by their traditional occupation of the family

The above table specifies about traditional occupation of the family among three unions in APSRTC. Out of the total respondents from all the union employees, majority of their traditional occupation of the family $(75.0 \%)$ are employees and from the remaining 9.5 percent are caste based profession, 9.0 percent are of their family occupation are agriculture and the remaining very few $(6.5 \%)$ are business people.

Table - 9: Distribution of the sample union employees of their previous occupation

\begin{tabular}{|c|c|c|c|c|}
\hline \multirow[t]{2}{*}{ Occupation } & \multicolumn{3}{|c|}{ Unions } & \multirow[t]{2}{*}{ Total } \\
\hline & NMU & $\mathbf{E U}$ & $\overline{\text { CITU }}$ & \\
\hline Student & $\begin{array}{l}73 \\
(48.7)\end{array}$ & $\begin{array}{l}13 \\
(43.3)\end{array}$ & $\begin{array}{l}12 \\
(60.0)\end{array}$ & $\begin{array}{l}98 \\
(49.0)\end{array}$ \\
\hline Un employment & $\begin{array}{l}64 \\
(42.7)\end{array}$ & $\begin{array}{l}10 \\
(33.3)\end{array}$ & $\begin{array}{l}4 \\
(20.0)\end{array}$ & $\begin{array}{l}78 \\
(39.0)\end{array}$ \\
\hline Employed & $\begin{array}{l}11 \\
(7.3)\end{array}$ & $\begin{array}{l}3 \\
(10.0)\end{array}$ & $\begin{array}{l}4 \\
(20.0)\end{array}$ & $\begin{array}{l}18 \\
(9.0)\end{array}$ \\
\hline Daily wage earners & $\begin{array}{l}2 \\
(1.3)\end{array}$ & $\begin{array}{l}4 \\
(13.3)\end{array}$ & - & $\begin{array}{l}6 \\
(3.0)\end{array}$ \\
\hline Total & $\begin{array}{l}150 \\
(100.0)\end{array}$ & $\begin{array}{l}30 \\
(100.0)\end{array}$ & $\begin{array}{l}20 \\
(100.0)\end{array}$ & $\begin{array}{l}200 \\
(100.0)\end{array}$ \\
\hline
\end{tabular}

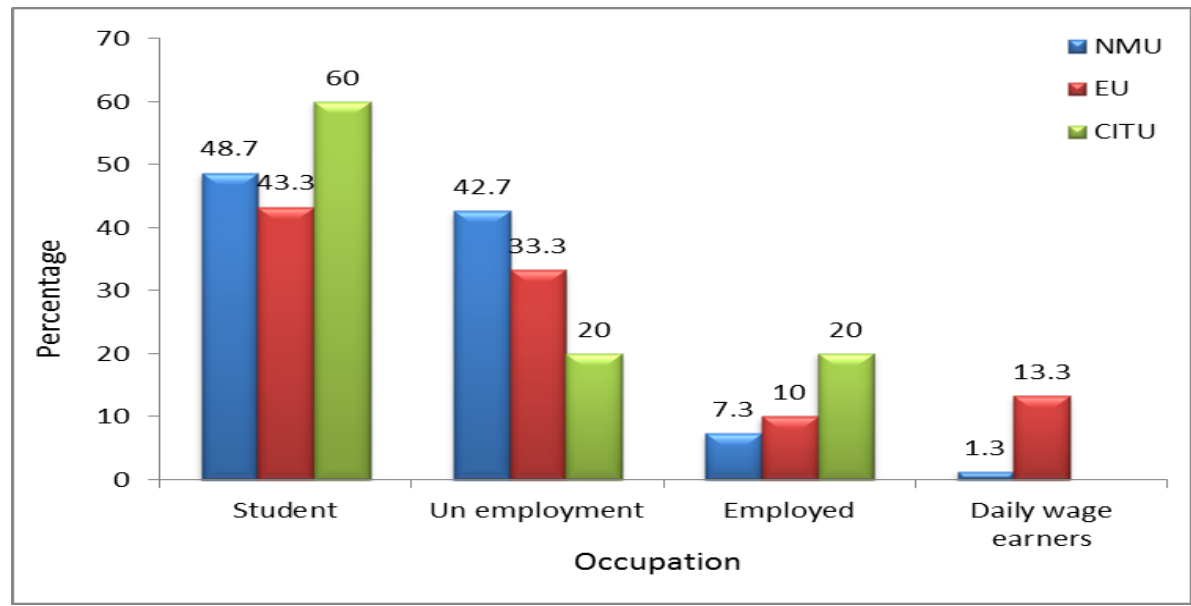

Figure-9: Distribution of the sample union employees of their previous occupation 
The above table-9 explains about the distribution of the above three types of union employees in APSRTC by their previous occupation. Out of the total respondents from all the union employees of their previous occupation, most of them $(49.0 \%)$ are students and from the remaining 39.0 percent are un employed, 9.0 percent are employed and the remaining very few (3.0\%) are daily wage earners.

Table - 10: Distribution of the sample union employees of their annual income of the family

\begin{tabular}{|c|c|c|c|c|}
\hline \multirow[t]{2}{*}{ Annual Income (Rs.) } & \multicolumn{3}{|l|}{ Unions } & \multirow[t]{2}{*}{ Total } \\
\hline & NMU & EU & CITU & \\
\hline Less than 50,000 & $\begin{array}{l}2 \\
(1.3)\end{array}$ & - & - & $\begin{array}{l}2 \\
(1.0)\end{array}$ \\
\hline 50,000 - 1 lakh & $\begin{array}{l}92 \\
(61.3)\end{array}$ & $\begin{array}{l}10 \\
(33.3)\end{array}$ & $\begin{array}{l}14 \\
(70.0)\end{array}$ & $\begin{array}{l}116 \\
(58.0)\end{array}$ \\
\hline 1 - 2 lakhs & $\begin{array}{l}54 \\
(36.0)\end{array}$ & $\begin{array}{l}20 \\
(66.7)\end{array}$ & $\begin{array}{l}5 \\
(25.0)\end{array}$ & $\begin{array}{l}79 \\
(39.5) \\
\end{array}$ \\
\hline 2-4 lakhs & $\begin{array}{l}2 \\
(1.3)\end{array}$ & - & $\begin{array}{l}1 \\
(5.0)\end{array}$ & $\begin{array}{l}3 \\
(1.5)\end{array}$ \\
\hline Total & $\begin{array}{l}150 \\
(100.0)\end{array}$ & $\begin{array}{l}30 \\
(100.0)\end{array}$ & $\begin{array}{l}20 \\
(100.0)\end{array}$ & $\begin{array}{l}200 \\
(100.0)\end{array}$ \\
\hline
\end{tabular}

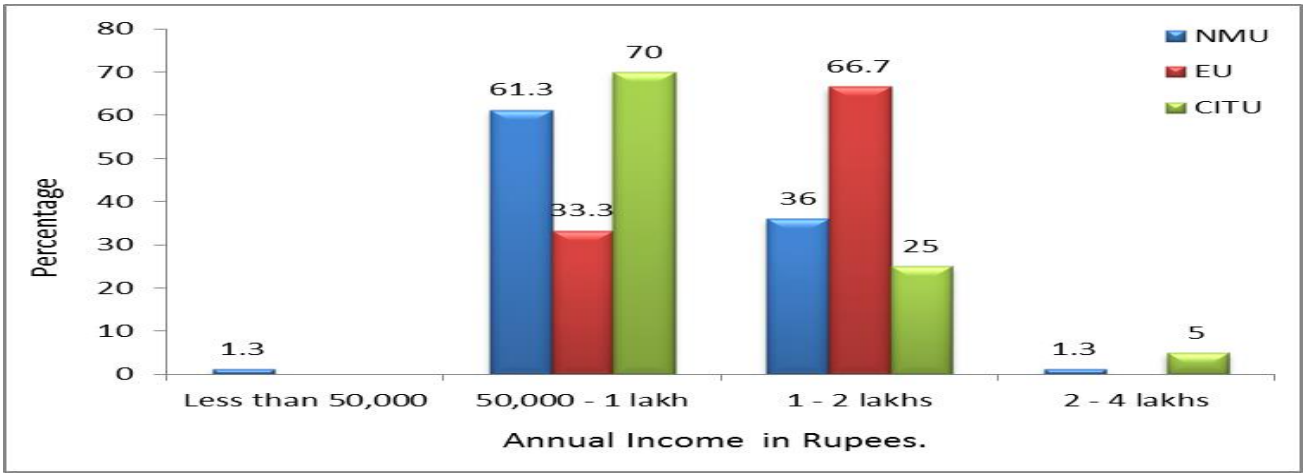

Figure - 10: Distribution of the sample union employees of their annual income of the family

The above table infers about the annual income of the family among the three unions. Out of the total respondents from all the union employees, more than half percent of employees family annual income is between Rs 50,000 to 1 Lakh then about $39.5 \%$ of employees annual income is between 1 to 2 lakhs and near or about $1 \%$ employees income is either low i.e less than 50,000 or more i.e. between 2 to 4 lakhs.

Table - 11: Experience of the sample union employees working in this profession

\begin{tabular}{|c|c|c|c|c|}
\hline \multirow[t]{2}{*}{ Experience } & \multicolumn{3}{|l|}{ Unions } & \multirow[t]{2}{*}{ Total } \\
\hline & NMU & $\mathbf{E U}$ & CITU & \\
\hline Below 5 years & $\begin{array}{l}20 \\
(13.3)\end{array}$ & $\begin{array}{l}3 \\
(10.0)\end{array}$ & $\begin{array}{l}3 \\
(15.0)\end{array}$ & $\begin{array}{l}26 \\
(13.0)\end{array}$ \\
\hline 6-10 years & $\begin{array}{l}68 \\
(45.3)\end{array}$ & $\begin{array}{l}7 \\
(23.3)\end{array}$ & $\begin{array}{l}9 \\
(45.0)\end{array}$ & $\begin{array}{l}84 \\
(42.0)\end{array}$ \\
\hline $11-15$ years & $\begin{array}{l}29 \\
(19.3)\end{array}$ & $\begin{array}{l}9 \\
(30.0)\end{array}$ & $\begin{array}{l}2 \\
(10.0)\end{array}$ & $\begin{array}{l}40 \\
(20.0)\end{array}$ \\
\hline $16-20$ years & $\begin{array}{l}33 \\
(22.0)\end{array}$ & $\begin{array}{l}11 \\
(36.7)\end{array}$ & $\begin{array}{l}6 \\
(30.0)\end{array}$ & $\begin{array}{l}50 \\
(25.0)\end{array}$ \\
\hline Total & $\begin{array}{l}150 \\
(100.0)\end{array}$ & $\begin{array}{l}30 \\
(100.0)\end{array}$ & $\begin{array}{l}20 \\
(100.0)\end{array}$ & $\begin{array}{l}200 \\
(100.0)\end{array}$ \\
\hline
\end{tabular}




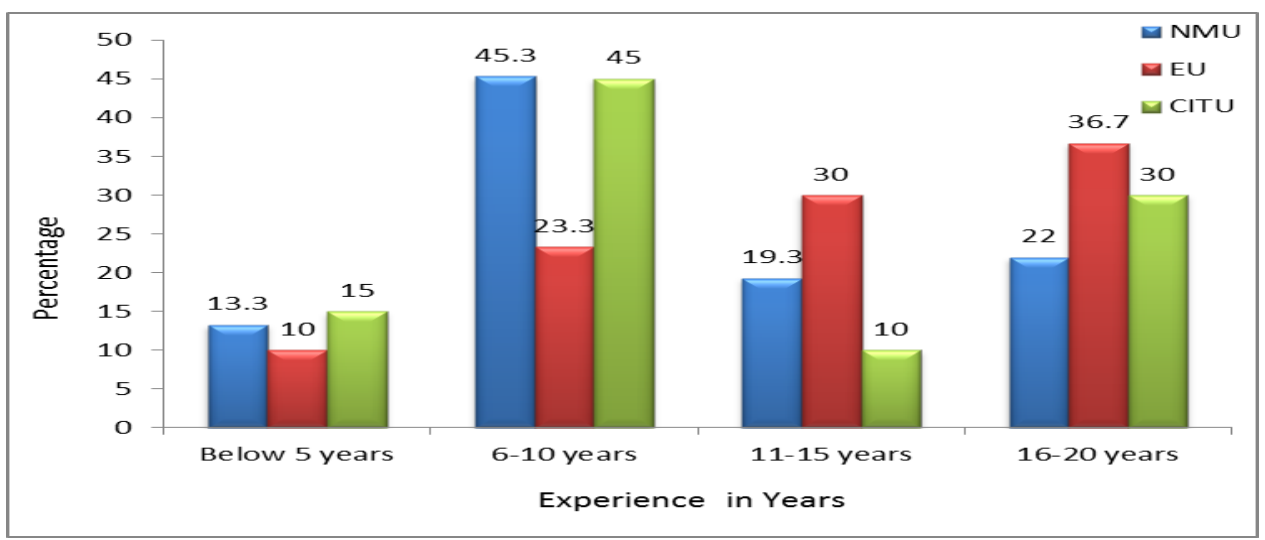

Figure - 11: Period of the sample union employees working in this profession

Table-11 designates the distribution professional experience among the three types of union in APSRTC. Majority of the employees (42.0\%) are having 6-10 years of experience, 13.0 percent are having below 5 years of experience as union employees. Among the total employees of NMU, most of them (45.3\%) are having 6-10 years of experience as a union employee, whereas EU employees, majority of their experience as a union employee (36.7\%) are having 16-20 years of experience and 30.0 percent are having 11-15 years of experience,. From the total CITU employees of their experience as union employees in APSRTC, most of them (45.0\%) are having 6-10 years of experience.

4. Findings

- The data reveals that male employees in APSRTC are dominating the female employees in number, and among which majority group of employees are from backward caste followed by forward caste and schedule caste. While most of the employees are married, a significant number of employees are unmarried.

- The education levels of the employees indicate that a dominated group are with intermediate qualification $(39.0 \%)$ followed by SSC $(31.0 \%)$, graduates $(16.5 \%)$ and post graduates

- Out of the total employees selected for data, conductors (47.5\%) are dominating with their number followed by drivers $(40.0 \%)$ and very few are $4^{\text {th }}$ class employees.

- According to the data, in NMU and CITU majority group of employees are with 6-10 years of experience, but in the case of EU, majority group of employees are having more than 11 years experience in the organization, and it shows that in three unions most of respondents are joined during 1999 to 2005 as union employees.

5. References

Anjana Raju, Jim Barreto. (1999).Trade Unionism in Goa: A Case Study of Zuhari Industries Ltd. And Goa Shipyard, Management and Labour Studies.24(4),219-224.

Arya, P.P. (1982). Labour Management Relations in Public Sector Undertakings, New Delhi, Deep and Deep Publications.

Bernstein, I.(1954).The Growth of American Unions. American Economic Review.

Chatterji, Rakhhari. (1980).Union Politics and the State - A Study, Mathur. A.S., and Raman, R.Trade Union Leadership in India. Agra University, Journal of Indian Labour Politics, New Delhi, South Asia Publishing.

Davio E. Guest and Philip Dewe. (1988).Why do Workers Belong to Trade Unions? A Social Psychological Study in the UK Electronic Industry. British Journal of Industrial Relations (London),26(2),178-93.

Deal, H.S. (1985).Trade Unionism in Public Sector - A Case Study of Punjab State Electricity Board, unpublished Ph.D. Thesis, Patiala, Punjab University.

\section{Copyrights}

Copyright for this article is retained by the author(s), with first publication rights granted to the journal.

This is an open-access article distributed under the terms and conditions of the Creative Commons Attribution license (http://creativecommons.org/licenses/by/4.0/) 